\title{
Ticks infesting wild small rodents in three areas of the state of São Paulo, Brazil
}

\author{
Carrapatos infestando pequenos roedores silvestres em \\ três municípios do estado de São Paulo, Brasil
}

\begin{abstract}
Thiago Fernandes Martins ${ }^{I^{*}}$ Marina Gea Peres ${ }^{\mathrm{II}}$ Francisco Borges Costa $^{\mathrm{I}}$ Thais Silva Bacchiega $^{\mathrm{II}}$ Camila Michele AppolinarioII João Marcelo Azevedo de Paula Antunes II Acácia Ferreira Vicente ${ }^{\text {II }}$ Jane Megid ${ }^{\text {II }}$ Marcelo Bahia Labruna ${ }^{I}$
\end{abstract}

\section{ABSTRACT}

From May to September 2011, a total of 138 wild rodents of the Cricetidae family were collected in the cities of Anhembi, Bofete and Torre de Pedra, in São Paulo State. All animals were examined for the presence of ticks, which were collected and identified at species level in the laboratory by morphological examination (for adults, nymphs and larvae) and molecular biology, by sequencing of a fragment of the 16S mitochondrial rDNA (for larvae). A total of 47 ticks (21 larvae and 26 nymphs) were collected from rodents, identified as 21 larvae and 23 nymphs of Amblyomma ovale (collected on Oligoryzomys nigripes, Oligoryzomys flavescens, Sooretamys agouya and Nectomys squamipes), two nymphs of Ixodes schulzei (O. nigripes and $\boldsymbol{O}$. flavescens) and an Amblyomma sculptum nymph in $\boldsymbol{S}$. agouya. The overall prevalence of parasitism by $\boldsymbol{A}$. ovale was $4.3 \%$ for larvae, and $10.1 \%$ for nymphs. The mean intensity of parasitism was 3.5 larvael parasitized animal, and 1.6 nymphs/parasitized animal. One $\boldsymbol{O}$. nigripes was found parasitized by both larva and nymph of $\boldsymbol{A}$. ovale, and another $\boldsymbol{O}$. nigripes was parasitized simultaneously by an I. schulzei nymph and five A. ovale nymphs. This research reports the following unpublished records: $A$. ovale on O. flavescens, O. nigripes and S. agouya; A. sculptum on S. agouya; and I. schulzei on $O$. flavescens and $O$. nigripes.

Key words: ticks, wild rodents, Amblyomma ovale, Amblyomma sculptum, Ixodes schulzei, Brazil.

RESUMO

De maio a setembro de 2011, um total de 138 roedores silvestres da família Cricetidae foram coletados nos municipios de Anhembi, Bofete e Torre de Pedra, no estado de São Paulo. Todos os animais foram examinados quanto à presença de carrapatos, os quais foram coletados e identificados ao nivel de espécie em laboratório, através de análises morfológicas (para adultos, ninfas e larvas) e por biologia molecular para confirmar estas análises, através do sequenciamento de um fragmento do gene 165 rDNA mitocondrial (para uma parte das larvas). Um total de 47 carrapatos (21 larvas e 26 ninfas) foi coletado dos roedores, sendo identificados como 21 larvas e 23 ninfas de Amblyomma ovale (coletados sobre Oligoryzomys nigripes, Oligoryzomys flavescens, Sooretamys agouya e Nectomys squamipes), duas ninfas de Ixodes schulzei (em 0 . nigripes e O. flavescens) e uma ninfa de Amblyomma sculptum em $\boldsymbol{S}$. agouya. A prevalência geral de parasitismo por A. ovale foi de $4,3 \%$ e de $10,1 \%$ para larvas e ninfas, respectivamente. As intensidades médias de parasitismo foram de 3,5 larvas/animal parasitado e de 1,6 ninfas/animal parasitado. Um O. nigripes foi encontrado parasitado simultaneamente por larva e ninfa de $\boldsymbol{A}$. ovale, e outro $\boldsymbol{O}$. nigripes estava parasitado simultaneamente por uma ninfa de I. schulzei e cinco ninfas de A. ovale. O presente trabalho reporta os seguintes registros inéditos: $A$. ovale em $\boldsymbol{O}$. flavescens, $\boldsymbol{O}$. nigripes e $S$. agouya; . sculptum em $S$. agouya; e I. schulzei em O. flavescens e O. nigripes.

Palavras-chave: carrapatos, roedores silvestres, Amblyomma ovale, Amblyomma sculptum, Ixodes schulzei, Brasil.

\section{INTRODUCTION}

Ticks are arthropod ectoparasites of the class Arachnida, with worldwide distribution, which parasitize terrestrial vertebrates, amphibians, reptiles, birds and mammals (BARROS-BATTESTI et al.,

IDepartamento de Medicina Veterinária Preventiva e Saúde Animal, Faculdade de Medicina Veterinária e Zootecnia, Universidade de São Paulo (USP), Av. Prof. Orlando Marques de Paiva, 87, 05508-000, São Paulo, SP, Brasil. E-mail: thiagodogo@hotmail.com. ${ }^{*}$ Corresponding author.

IDepartamento de Higiene Veterinária e Saúde Pública, Faculdade de Medicina Veterinária e Zootecnia, Universidade Estadual Paulista (UNESP), Botucatu, SP, Brasil. 
2006). Given the particularities of their feeding habits, ticks are considered the first group of importance as vectors of infectious diseases to animals, and the second for humans (JONGEJAN \& UILENBERG, 2004). Tick-borne microorganisms include viruses, bacteria, protozoa and helminths (BARROSBATTESTI et al., 2006). In Brazil, bacteria of the genus Rickettsia are considered the most important tick-borne agents, which are spotted fever diseases in different regions of the country (LABRUNA et al., 2011). The species of ticks which infest domestic animals are the most studied; however, the species that parasitize wildlife are still poorly known, especially in relation to their taxonomy, biology, ecology, geographical distribution, usual host, and vector capacity of bioagents (BARROSBATTESTI et al., 2006). Recent studies have shown that small rodents are important hosts for several species of Ixodidae ticks, especially for immature stages (GUGLIELMONE \& NAVA 2010, 2011). In this context, the aim of this study was to report the occurrence of ticks infesting wild rodents in three areas of the state of São Paulo, southeastern Brazil.

\section{MATERIALS AND METHODS}

Ticks were collected from wild rodents from May to September 2011 in three municipalities located in the State of São Paulo: Anhembi (22 47'09.11''S, 4807'30.90”W), Bofete $\left(23^{\circ} 05^{\prime} 54.51^{\prime \prime} \mathrm{S}, 48^{\circ} 11^{\prime} 26.61^{\prime \prime} \mathrm{W}\right)$ and Torre de Pedra (2314'58.76"S, 48 11'39.49'W). Rodents were captured as part of a study on the wild cycle of the Vaccinia viruses, in which rodents were evaluated as potential reservoirs of the virus (PERES et al., 2013). Rodent captures were performed with Sherman and pitfall intercepts traps, as previously described (PERES et al., 2013). Rodents were identified to species according to BONVICINO et al. (2008), REIS et al. (2006) and WILSON \& REEDER (2005). Attached ticks were removed using tweezers and stored in $70 \%$ alcohol until its taxonomic identification in the laboratory, following taxonomic keys for tick genera (BARROS-BATTESTI et al., 2006) and for nymph of the genus Amblyomma (MARTINS et al., 2010), and morphological description previously reported for the nymph of Ixodes schulzei (BARROSBATTESTI et al., 2007). In the case of Amblyomma spp. larvae, collected samples were compared morphologically with Amblyomma ovale larvae originated from a laboratory colony, as previously described (BARBIERI et al., 2008; SZABÓ et al., 2013.). The morphological identification of these larvae was confirmed by molecular analysis of a few specimens, which had the DNA extracted by the guanidine isothiocyanate method (SANGIONI et al., 2005) and tested by polymerase chain reaction (PCR) targeting a fragment of 460 nucleotides of the tick mitochondrial 16S rDNA gene, according to MANGOLD et al. (1998). Amplicons of the expected size were generated to DNA sequencing in an automatic sequencer (Model ABI 3500 Genetic Analyzer; Applied Biosystems/Thermo Fisher Scientific, Foster City, CA, USA) according to manufacturer's instructions. For each host species, prevalence and mean intensity of infestation by certain tick species was calculated following BUSH et al. (1997). In this case, prevalence $=$ number of infested individuals / number of examined individuals $\mathrm{X} 100$; mean intensity $=$ total number of ticks/number of infested individuals.

\section{RESULTS}

A total of 138 rodents of the Cricetidae family was captured and examined for the presence of ticks. Animals taken belonged to eight different species, of which 75 Oligoryzomys nigripes, 31 Oligoryzomys flavescens, 14 Sooretamys agouya, eight Akodon montensis, four Nectomys squamipes, four Calomys tener, one Juliomys pictipes, and one Necromys lasiurus. A total of 47 ticks (21 larvae and 26 nymphs) were collected from rodents and identified as 21 larvae and 23 nymphs of $\boldsymbol{A}$. ovale (collected on $\boldsymbol{O}$. nigripes, $\boldsymbol{O}$. flavescens, $S$. agouya and $N$. squamipes in at least one of the three sampled municipalities), two nymphs of $\boldsymbol{I}$. schulzei (one on $\boldsymbol{O}$. nigripes from Anhembi, one on $\boldsymbol{O}$. flavescens from Bofete) and a Amblyomma sculptum nymph on $\boldsymbol{S}$. agouya from Anhembi.

Once the tick $\boldsymbol{A}$. ovale accounted for 44 $(93.7 \%)$ of the 47 collected ticks, prevalence and mean intensity of parasitism values were calculated only for this tick species, as detailed in table 1 . The overall prevalence of parasitism by $\boldsymbol{A}$. ovale was $4.3 \%$ for larvae, and $10.1 \%$ for nymphs. The mean intensity of parasitism was 3.5 larvae/infested animal, and 1.6 nymphs/infested animal. Considering the four species of rodents in which larvae or nymphs of $\boldsymbol{A}$. ovale were collected, prevalence values ranged from 5.3 to $6.5 \%$ for larvae, and from 3.2 to $25.0 \%$ for nymphs. The mean intensity of larvae ranged from 2.5 to 4.0 larvae per infested animal, whereas the mean intensity of nymphs ranged from 1.0 to 1.8 nymphs per infested animal. Only one individual rodent (O. nigripes from Bofete) was simultaneously infested by larva and 
Table 1 - Amblyomma ovale ticks collected from wild rodents (Oligoryzomys nigripes, Oligoryzomys flavescens, Sooretamys agouya, Nectomys squamipes, Akodon montensis, Calomys tener, Juliomys pictipes, Necromys lasiurus) that were captured in three municipalities (Anhembi, Bofete, and Torre de Pedra) of the state of São Paulo, Brazil, from May to September 2011.

\begin{tabular}{|c|c|c|c|c|c|c|c|}
\hline \multirow[t]{2}{*}{ Host } & \multirow{2}{*}{$\begin{array}{l}\text { Anhembi } \\
\text { Nymph }\end{array}$} & \multicolumn{2}{|c|}{-----------------Bofete---------------- } & \multicolumn{2}{|c|}{-----------Torre de Pedra----------- } & \multicolumn{2}{|c|}{------------------Total------------------ } \\
\hline & & Larva & Nymph & Larva & Nymph & Larva & Nymph \\
\hline O. nigripes & $7 / 48(14.5) ; 2.3$ & $2 / 18(11.1) ; 1.0$ & $1 / 18(5.6) ; 1.0$ & $2 / 9(22.2) ; 7.0$ & $3 / 9(33.3) ; 1.0$ & $4 / 75(5.3) ; 4.0$ & $11 / 75(14.6) ; 1.8$ \\
\hline $\begin{array}{l}\text { o. } \\
\text { flavescens }\end{array}$ & $0 / 14(0) ; 0$ & $1 / 13(7.7) ; 1.0$ & $1 / 13(7.7) ; 1.0$ & $1 / 4(25.0) ; 4.0$ & $0 / 4(0) ; 0$ & $2 / 31(6.5) ; 2.5$ & $1 / 31(3.2) ; 1.0$ \\
\hline S. agouya & $1 / 13(7.6) ; 1.0$ & $0 / 1(0) ; 0$ & $0 / 1(0) ; 0$ & - & - & $0 / 14(0) ; 0$ & $1 / 14(7.1) ; 1.0$ \\
\hline $\begin{array}{l}N . \\
\text { squamipes }\end{array}$ & $0 / 3(0) ; 0$ & $0 / 1(0) ; 0$ & $1 / 1(100) ; 1.0$ & - & - & $0 / 4(0) ; 0$ & $1 / 4(25.0) ; 1.0$ \\
\hline $\begin{array}{l}\text { A. } \\
\text { montensis }\end{array}$ & - & $0 / 8(0) ; 0$ & $0 / 8(0) ; 0$ & - & - & $0 / 8(0) ; 0$ & $0 / 8(0) ; 0$ \\
\hline C. tener & $0 / 2(0) ; 0$ & $0 / 2(0) ; 0$ & $0 / 2(0) ; 0$ & - & - & $0 / 4(0) ; 0$ & $0 / 4(0) ; 0$ \\
\hline J. pictipes & - & - & - & $0 / 1(0) ; 0$ & $0 / 1(0) ; 0$ & $0 / 1(0) ; 0$ & $0 / 1(0) ; 0$ \\
\hline N. lasiurus & - & $0 / 1(0) ; 0$ & $0 / 1(0) ; 0$ & - & - & $0 / 1(0) ; 0$ & $0 / 1(0) ; 0$ \\
\hline Total & $8 / 80(10.0) ; 2.1$ & $3 / 44(6.8) ; 1.0$ & $3 / 44$ (6.8); 1.0 & $3 / 14(2.1) ; 6.0$ & $3 / 14(2.1) ; 1.0$ & $6 / 138(4.3) ; 3.5$ & $14 / 138(10.1) ; 1.6$ \\
\hline
\end{tabular}

$*:$ Mean intensity $=$ total number of ticks / number of infested animals.

- : No animal of this species was collected in this locality.

nymph of $\boldsymbol{A}$. ovale. The $\boldsymbol{O}$. nigripes specimen that was parasitized by a I. schulzei nymph also contained five nymphs of $\boldsymbol{A}$. ovale.

Of the 21 larvae that were morphologically identified as $\boldsymbol{A}$. ovale through comparison with larvae derived from a laboratory colony, four larvae (one from $\boldsymbol{O}$. nigripes and one from $\boldsymbol{O}$. flavescens from Torre de Pedra, two from $\boldsymbol{O}$. nigripes from Bofete) were subjected to PCR for the mitochondrial $16 \mathrm{~S}$ rDNA gene, resulting in 409-412-bp DNA sequences that differed to each other by only $1(0.2 \%)$ to at most 16 nucleotides $(3.9 \%)$. These four sequences were shown to be 96 to $99 \%$ identical to corresponding sequences of $\boldsymbol{A}$. ovale in GenBank (AF541255, KF179347, JN573304, FJ424409). After A. ovale, the sequences from GenBank with larger similarity values to these larvae were Amblyomma aureolatum (KF179343), Amblyomma multipunctum (KC677673), Amblyomma naponense (KC677674) and Amblyomma dubitatum (DQ858954), with similarity values always lower than $88 \%$. The four sequences of $\boldsymbol{A}$. ovale larvae generated in this study were deposited in GenBank under accession number KR605466-KR605469. Voucher tick specimens collected in this study were deposited in the tick collection "Coleção Nacional de Carrapatos" (CNC) of the Faculty of Veterinary Medicine of the University of São Paulo, under the accession numbers CNC-2457 to CNC-2462.

\section{DISCUSSION}

The tick $\boldsymbol{A}$. ovale was the major species found in small rodents in this study, the most prevalent and abundant (Table 1). Previous studies indicated that immature $A$. ovale parasitize mainly rodents of the family Cricetidae (SZABÓ et al., 2013; SPONCHIADO et al., 2015) and Echimyidae (SARAIVA et al., 2012), whereas the adult stage parasitizes chiefly wild carnivores and domestic dogs (GUGLIELMONE et al., 2003). In this study, immature $\boldsymbol{A}$. ovale were reported on four species of rodents, which includes the first records for $\boldsymbol{O}$. flavescens, $\boldsymbol{O}$. nigripes and $\boldsymbol{S}$. agouya. Generally, the values of prevalence and mean intensity of $\boldsymbol{A}$. ovale reported in this study were similar or within the range reported for other species of small rodents in the state of São Paulo (SZABÓ et al., 2013) and Mato Grosso do Sul (SPONCHIADO et al., 2015).

In the present study, we found an $\boldsymbol{A}$. sculptum nymph parasitizing $S$. agouya for the first time. Although $\boldsymbol{A}$. sculptum (formerly known as Amblyomma cajennense) is widely distributed in southeastern Brazil (NAVA et al., 2014), this tick species has a preference for medium to largesized mammals (BARROS-BATTESTI et al., 2006) and is rarely found on Cricetidae rodents, such as Cerradomys subflavus and $\boldsymbol{O}$. nigripes in Minas 
Gerais (SARAIVA et al., 2012) and Calomys callosus and Rhipidomys macrurus in Mato Grosso do Sul (SPONCHIADO et al., 2015).

The present reports of I. schulzei on two species of Oligoryzomys are unprecedented for this tick. Although all parasitic stages of I. schulzei are associated with Cricetidae rodents, the vast majority of records have been on a single species, $N$. squamipes (LABRUNA et al., 2003; SARAIVA et al., 2012). There are occasional records on $A$. montensis and Euryoryzomys russatus in the state of Paraná (ONOFRIO et al., 2013).

In this study, $\boldsymbol{A}$. ovale was the most frequent tick on small rodents in three areas of the state of São Paulo. Findings of larvae and nymphs parasitizing small rodents indicated that $A$. ovale is established in the studied area, where wild carnivores and/or domestic dogs should be serving as hosts for the adult stage of the tick. In fact, during the present fieldwork, two adult males of $\boldsymbol{A}$. ovale were collected from a free-ranging coati (Nasua nasua) in Anhembi (CNC-2464). Human parasitism by the adult stage of A. ovale is relatively common in areas of occurrence of this tick species (LABRUNA et al., 2005; SZABÓ et al., 2006). Once A. ovale is vector of Hepatozoon canis for domestic dogs (FORLANO et al., 2005) and a causative agent of spotted fever (Rickettsia sp. strain Atlantic Forest) for humans in the state of São Paulo (SZABÓ et al., 2013), studies such as the present one are essential for a better understanding of the natural history of $\boldsymbol{A}$. ovale and its associated pathogens.

\section{BIOETHICS AND BIOSSECURITY COMMITTEE APPROVAL}

Protocol no. 112/201-CEUA of the Universidade Estadual Paulista Júlio de Mesquita Filho (UNESP-Botucatu).

\section{ACKNOWLEDMENTS}

This study received financial support from the Fundação de Amparo à Pesquisa do Estado de São Paulo (FAPESP) and Conselho Nacional de Desenvolvimento Científico e Tecnológico (CNPq). We thank the Instituto Chico Mendes de Conservação da Biodiversidade (ICMBio) for permission to capture rodents (number 23918-1).

\section{REFERENCES}

BARBIERI, F. S. et al. Description of the larva of Amblyomma ovale Koch, 1884 (Acari: Ixodidae) by light and scanning electron microscopy. Systematic and Applied Acarology, v.13, n.2, p.109-119, 2008. Available from: <http://www.nhm. ac.uk/hosted-sites/acarology/saas/saa/abst13/saa13_12.html>. Accessed: Jan. 11, 2015.
BARROS-BATTESTI, D. M. et. al. Carrapatos de importância médico-veterinária da região neotropical: um guia ilustrado para identificação de espécies. São Paulo: Vox/ICTTD-3/Butantan, 2006, p. 223.

BARROS-BATTESTI, D. M. et al. Description of the immature stages and redescription of the female of Ixodes schulzei Aragão \& Fonseca, 1951 (Acari: Ixodidae), an endemic tick species of Brazil. Systematic Parasitology, v.68, n.3, p.157-166, 2007. Available from: $\quad<$ http://link.springer.com/article/10.1007\%2Fs11230-0079100-z>. Acesso em: 11 jan. 2015.

BONVICINO, C. R. et. al. Guia de roedores do Brasil, com chaves para gêneros baseados em caracteres externos. Rio de Janeiro: Centro Pan-Americano de Febre Aftosa - OPAS/OMS, p.120, 2008.

BUSH, A. O. et al. Parasitology meets ecology on its own terms: Margolis et al. revisited. Journal of Parasitology, v. 83, n. 4, p. 575-583, 1997. Available from: <http://www.fcfar.unesp.br/ arquivos/494986.pdf>. Accessed: Jan. 22, 2015.

FORLANO, M. et al. Diagnosis of Hepatozoon spp. in Amblyomma ovale and its experimental transmission in domestic dogs in Brazil. Veterinary Parasitology, v. 134, n. 1-2, p. 1-7, 2005. Available from: <http://dx.doi.org/10.1016/j. vetpar.2005.05.066>. Accessed: Jan. 22, 2015.

GUGLIELMONE, A. A. et. al. Amblyomma aureolatum (Pallas, 1772) and Amblyomma ovale Kock, 1844: hosts, distribution and 16S rDNA sequences. Veterinary Parasitology, v.113, n.34, p.273-288, 2003. Available from: <http://dx.doi.org/10.1016/ S0304-4017(03)00083-9>. Accessed: Jan. 25, 2015.

GUGLIELMONE, A. A.; NAVA, S. Rodents of the subfamily Caviinae (Hystricognathi: Caviidae) as hosts for hard ticks (Acari: Ixodidae). Mastozoología Neotropical, v.17, n.2, p.279-286, 2010. Available from: <http://www.scielo.org.ar/pdf/mznt/v17n2/ v17n2a03.pdf $>$. Accessed: Jan. 25, 2015.

GUGLIELMONE, A. A.; NAVA, S. Rodents of the subfamily Sigmodontinae (Myomorpha: Cricetidae) as hosts for South American hard ticks (Acari: Ixodidae) with hypotheses on life history. Zootaxa, v. 2904, p. 45-65, 2011. Available from: <http:// www.mapress.com/zootaxa/2011/f/z02904p065f.pdf>. Accessed: Jan. 25, 2015.

JONGEJAN, F.; UILENBERG, G. The global importance of ticks. Parasitology, v. 129, Suppl. S1, S3-S14, 2004. Available from: $<$ http://cbpv.org.br/artigos/CBPV artigo 017.pdf>. Accessed: May. 01, 2015.

LABRUNA, M. B. et al. New records and laboratory-rearing data for Ixodes schulzei (Acari: Ixodidae) in Brazil. Journal of Medical Entomology, v. 40, n. 1, p. 116-118, 2003. Available from: <http://dx.doi.org/10.1603/0022-2585-40.1.116>. Accessed: May. 06, 2015.

LABRUNA, M. B. et al. Ticks (Acari: Ixodidae) from the state of Rondônia, western Amazon, Brazil. Systematic and Applied Acarology, v. 10, p. 17-32, 2005. Available from: <http://www. nhm.ac.uk/hosted_sites/acarology/saas/saa/abst10/saa10_04. html>. Accessed: May. 06, 2015.

LABRUNA, M. B. et al. Rickettsiosis in Latin America, Caribbean, Spain and Portugal. Revista MVZ Córdoba, v. 16, n. 2, p. 2435- 
2457, 2011. Available from: <http://www.scielo.org.co/pdf/mvz/ v16n2/v16n2a02.pdf>. Accessed: May. 06, 2015.

MANGOLD, A. J. et al. Mitochondrial 16S rDNA sequences and phylogenetic relationships of species of Rhipicephalus and other tick genera among Metastriata (Acari: Ixodidae). Parasitology Research, v. 84, n. 6, p. 478-484, 1998. Available from: <http:// dx.doi.org/10.1007/s004360050433.PMid:9660138>. Accessed: Dec. 17, 2014.

MARTINS, T. F. et al. Nymphs of the genus Amblyomma (Acari: Ixodidae) of Brazil: descriptions, redescriptions, and identification key. Ticks and Tick-borne Diseases, v. 1, n. 2, p. 75-99, 2010 Available from: <http://dx.doi.org/10.1016/j.ttbdis.2010.03.002>. Accessed: May. 26, 2014.

NAVA, S. et al. Reassessment of the taxonomic status of Amblyomma cajennense (Fabricius, 1787) with the description of three new species, Amblyomma tonelliae n. sp., Amblyomma interandinum n. sp. and Amblyomma patinoi n. sp., and reinstatement of Amblyomma mixtum Koch, 1844 and Amblyomma sculptum Berlese, 1888 (Ixodida: Ixodidae). Ticks and Tick-borne Diseases, v. 5, n. 3, p. 252-276, 2014. Available from: < http://dx.doi.org/10.1016/j.ttbdis.2013.11.004>. Accessed: Apr. 11, 2014.

ONOFRIO, V. C. et al. Noteworthy records of Ixodes schulzei (Acari: Ixodidae) on rodents from the State of Parana, southern Brazil. Revista Brasileira de Parasitologia Veterinária, v. 22, n. 1, p. $159-161,2013$. Available from: <http://www.scielo.br/ pdf/rbpv/v22n1/0103-846X-rbpv-22-01-159.pdf>. Accessed: Jun. 13, 2014.

PERES, M. G. et al. Serological study of vaccinia virus reservoirs in areas with and without official reports of outbreaks in cattle and humans in São Paulo, Brazil. Archives of Virology, v. 158, n. 12, p. 2433-2441, 2013. Available from: <http://www.ncbi.nlm. nih.gov/pmc/articles/PMC3830743/pdf/705_2013_Article_1740. pdff $>$. Accessed: Jul. 22, 2014.
REIS, N. R. et al. Mamíferos do Brasil. Londrina: UEL, 2006, p. 437.

SANGIONI, L.A. et al. Rickettsial infection in animals and Brazilian spotted fever endemicity. Emerging Infectious Diseases, v. 11, n. 2, p. 265-270, 2005. Available from: <http:// www.ncbi.nlm.nih.gov/pmc/articles/PMC3320454/>. Accessed: Jul. 24, 2014.

SARAIVA, D. G. et al. Ticks (Acari: Ixodidae) associated with small terrestrial mammals in the state of Minas Gerais, southeastern Brazil. Experimental and Applied Acarology, v. 58, n. 2, p. 159 166, 2012. Available from: $<$ http://link.springer.com/article/10.10 07\%2Fs10493-012-9570-9>. Accessed: Jul. 22, 2014.

SPONCHIADO, J. et al. Association patterns of ticks (Acari: Ixodida: Ixodidae, Argasidae) of small mammals in Cerrado fragments, western Brazil. Experimental and Applied Acarology, v. 65, n. 3, p. 389-401, 2015. Available from: <http:// link.springer.com/article/10.1007\%2Fs 10493-014-9877-9>. Accessed: Apr. 23, 2015.

SZABÓ, M. P. J. et al. Ticks (Acari: Ixodidae) parasitizing humans in an Atlantic rainforest reserve of Southeastern Brazil: notes on host suitability. Experimental and Applied Acarology, v. 39, n. 3-4, p. 338-346, 2006. Available from: <http://link.springer.com/ar ticle/10.1007\%2Fs10493-006-9013-6>. Accessed: Mar. 05, 2015.

SZABÓ M. P. J. et al. In vitro isolation from Amblyomma ovale (Acari: Ixodidae) and ecological aspects of the Atlantic rainforest Rickettsia, the causative agent of a novel spotted fever rickettsiosis in Brazil. Parasitology, v. 140, n. 6, p. 719-728, 2013. Available from: $\quad<$ http://journals.cambridge.org/action/displayAbstract?fr omPage $=$ online \&aid $=8871189 \&$ fileId $=$ S0031182012002065 $>$. Accessed: Mar. 05, 2015.

WILSON, D. E.; REEDER, D. M. Mammal species of the world: a taxonomic and geographic reference. Baltimore: Johns Hopkins University, 2005, p.142. 